\title{
Social dominance in prepubertal dairy heifers allocated in continuous competitive dyads: Effects on body growth, metabolic status, and reproductive development
}

\author{
C. Fiol, ${ }^{* 1}$ M. Carriquiry, $†$ and R. Ungerfeld $\ddagger$ \\ *Departamento de Bovinos, Instituto de Producción Animal, Facultad de Veterinaria, Universidad de la República, Ruta 1 km 42.5, 80100 , \\ San José, Uruguay \\ †Departamento de Producción Animal y Pasturas, Facultad de Agronomía, Universidad de la República, Av. E. Garzón 780, 12900, Montevideo, \\ Uruguay \\ ‡Departamento de Fisiología, Facultad de Veterinaria, Universidad de la República, Lasplaces 1550, 11600, Montevideo, Uruguay
}

\begin{abstract}
The objective of this study was to compare the body weight (BW) and size, metabolic status, and reproductive development of dominant and subordinate prepubertal dairy heifers allocated in competitive dyads. Sixteen Holstein and Jersey $\times$ Holstein prepubertal heifers (means \pm SEM; $250.8 \pm 9.8$ d; $208.5 \pm 13.9$ $\mathrm{kg}$ of $\mathrm{BW}$ ) were assigned to 8 homogeneous dyads according to breed, age, and BW. Dyads were housed in pens separated $1 \mathrm{~m}$ from each other during $120 \mathrm{~d}$, receiving a total mixed ration on a $5 \%$ restriction of their potential dry matter intake, and had access to the same feeder $(60 \mathrm{~cm})$ throughout the experiment. Dominant and subordinate heifers were defined based on the winning agonistic interactions in each dyad. Body development was recorded every $20 \mathrm{~d}$ in all heifers, and blood samples were collected on the same days to determine endocrine and metabolic status. The maximum follicle diameter, number of follicles $>6 \mathrm{~mm}$, and the presence of corpus luteum were observed weekly by ultrasound. Heifer BW (269.3 vs. $265.3 \pm 1.5 \mathrm{~kg}$ ) and average daily gains ( 0.858 vs. $0.770 \pm 0.02 \mathrm{~kg} / \mathrm{d})$ were greater in dominant than subordinate heifers. On d 30, 37 , and 53, dominant heifers had more follicles than subordinate heifers, and maximum follicle diameter was greater in dominant than in subordinate heifers (10.0 vs. $9.0 \pm 0.3 \mathrm{~mm})$. Dominant heifers achieved puberty earlier than subordinate heifers $(313.9 \pm 4.9$ vs. 329.6 \pm 5.7 d) with similar BW $(279.4 \pm 2.6$ vs. $277.4 \pm 5.8$ $\mathrm{kg})$. Glucose concentrations were greater in dominant than subordinate heifers $(89.2$ vs. $86.8 \pm 1.2 \mathrm{mg} / \mathrm{dL})$, but cholesterol concentrations were greater in subor-
\end{abstract}

Received August 6, 2016.

Accepted November 15, 2016.

${ }^{1}$ Corresponding author: cfiolepera@gmail.com dinate than dominant heifers (86.1 vs. $90.2 \pm 2.6 \mathrm{mg}$ / $\mathrm{dL}$ ). We concluded that, under continuous competitive situations, dominant heifers were more precocious than subordinate ones, achieving an earlier puberty. Dominant heifers had greater body growth and glucose concentrations than subordinate heifers, which may be responsible, at least in part, for the differences on reproductive development between heifers of different social status.

Key words: replacement heifer, social behavior, social hierarchy, puberty

\section{INTRODUCTION}

Raising replacement heifers for dairy farms is expensive; thus, any increase in efficiency during this period has important consequences in reducing costs (Tozer and Heinrichs, 2001). Although age at first calving is one of the main determinants of productive success (Abeni et al., 2000; Pirlo et al., 2000), BW at calving and rate of growth before puberty can affect the maximum milk produced in the first lactation (Zanton and Heinrichs, 2005). In Uruguay, most dairy farmers maintain their heifers on low-quality pastures, which has been shown to increase age at first calving (36 mo; Conaprole, 2008) compared with the recommended 24 mo (Heinrichs and Swartz, 1990). In this context, intensive feeding systems, in which heifers are fed a TMR, are an important management tool to improve dairy heifer-rearing programs. Under these systems, social dominance and competition for feed may influence access to food and thus, heifer growth (DeVries, 2010). Management practices that involve high competition levels for feeding are major stressors that may have a negative effect on access to food and growth, raising welfare concerns, and thus, the need to develop alternative management.

Social dominance, the relationship of dominance-subordination established between 2 individuals (Drews, 
1993), has direct consequences on productive and reproductive results. Milk yield and fertility of dairy cows increased with social rank (Dobson and Smith, 2000; Phillips and Rind, 2002; Val-Laillet et al., 2008) and high-ranked beef cows were rebred earlier during the postpartum period compared with low-ranked cows (Landaeta-Hernández et al., 2013). In growing animals, high-ranked male lambs had greater ADG and a precocious increase of scrotal circumference, semen production, and sexual behavior compared with low-ranked lambs (Ungerfeld and González-Pensado, 2008). The effects of social dominance on an animal's performance may be exacerbated by management conditions that determine increased competition for resources (reduced feeding space or overstocking on intensive feeding systems; Val-Laillet et al., 2008; Manteca, 2009). Great levels of competition between heifers at the feedbunk provoked greater variability in ADG (Longenbach et al., 1999; González et al., 2008), whereas other studies suggested that high-ranked heifers gained more BW than low-ranked heifers (Greter et al., 2010).

Metabolic status in prepubertal heifers is affected by multiple factors, especially, nutrition and growth rate (Abeni et al., 2000, 2012). Depending on nutritional levels, Holstein and Jersey heifers can reach puberty at

Table 1. Composition and nutritive value (\% unless otherwise noted; mean $\pm \mathrm{SD}$ ) of the $\mathrm{TMR}^{1}$ (on DM basis) fed to prepubertal dairy heifers in 2 experimental periods

\begin{tabular}{lcc}
\hline & \multicolumn{2}{c}{ Experimental period } \\
\cline { 2 - 3 } Item & $\mathrm{d} 1$ to 46 & $\mathrm{~d} 47$ to 120 \\
\hline Ingredient & 58.3 & - \\
Corn silage & - & 59.3 \\
Pasture silage & 28 & 32 \\
Ground corn grain & 12.6 & 7.6 \\
Soybean meal & 0.5 & 0.5 \\
Urea & 0.5 & 0.5 \\
Commercial premix & & \\
Chemical composition & $30.3 \pm 1.3$ & $57.1 \pm 2.6$ \\
DM & $7.0 \pm 0.2$ & $11.3 \pm 1.9$ \\
Ash & $14.2 \pm 0.6$ & $13.8 \pm 2.8$ \\
CP & $27.4 \pm 2.8$ & $20.1 \pm 1.3$ \\
ADF & $50.7 \pm 4.6$ & $35.1 \pm 5.9$ \\
NDF & $2.6 \pm 0.2$ & $2.4 \pm 0.4$ \\
Ether extract & 2.37 & 2.46 \\
ME ${ }^{3}$ (Mcal/kg) & 60.0 & 59.1 \\
CP:ME (g/Mcal) & & \\
\hline
\end{tabular}

${ }^{1}$ Diet was formulated for $0.800 \mathrm{~kg} / \mathrm{d}$ of ADG (NRC, 2001).

${ }^{2}$ One hundred grams contained $0.8 \mathrm{~g}$ of Rumensin (Elanco Animal Health. Indianapolis, IN), $20 \mathrm{~g}$ of calcium carbonate, $5 \mathrm{~g}$ of mineral and vitamin premix, $7 \mathrm{~g}$ of $\mathrm{MgO}, 36 \mathrm{~g}$ of sodium bicarbonate, $2 \mathrm{~g}$ of Procreatin 7 (Philips Lesaffe Animal Care, Lyon France), $5 \mathrm{~g}$ of salt, $3 \mathrm{~g}$ of Safmannan (Philips Lesaffe Animal Care), and $21.2 \mathrm{~g}$ of wheat bran.

${ }^{3}$ Estimated according to the NRC (2001).
280 to 360 and 330 to $390 \mathrm{~d}$, respectively (Stewart et al., 1980). Although BW gain, age, and breed are directly related to the onset of ovarian cyclic activity, many metabolic hormones and metabolites are important signals for follicular development and initiation of puberty (Yelich et al., 1995, 1996; Chelikani et al., 2003). Therefore, it is expected that any alteration of heifer nutritional status (such as that provoked by high competition rates due to dominance status) may determine changes in growth rate, and thus, affect metabolite and endocrine profile and reproductive development.

We hypothesized that in heifers allocated continuously in competitive dyads (1) dominant heifers have greater body growth rate and follicle size and achieve puberty earlier than subordinate heifers, and (2) dominant heifers present a metabolic and endocrine profile that reflect a "more positive" energy balance (greater serum insulin, IGF-I, glucose, cholesterol, and urea) than subordinate heifers. Therefore, the objective of the present study was to compare BW and size, metabolic status, and reproductive development of dominant and subordinate prepubertal dairy heifers allocated in competitive dyads.

\section{MATERIALS AND METHODS}

\section{Animals and Housing}

Animal care, handling, and protocols were approved by the Comisión Honoraria de Experimentación Animal (Universidad de la República, Uruguay). The study was performed in the Campo Experimental number 2 of the Facultad de Veterinaria, San José, Uruguay $\left(34^{\circ} 40^{\prime} \mathrm{S}\right.$, $56^{\circ} 32^{\prime} \mathrm{W}$ ) from October to March. Sixteen Holstein (n $=12)$ and Jersey $\times$ Holstein $(\mathrm{n}=4)$ prepubertal heifers $(250.8 \pm 9.8 \mathrm{~d} ; 208.5 \pm 13.9 \mathrm{~kg}$ of BW; mean \pm SEM), that were managed similarly before the study, were selected from the herd of the experimental farm and were allocated to 8 homogeneous dyads, according to breed, age, and BW.

Each dyad was allocated for $120 \mathrm{~d}$ in shed pens $(5 \times$ $8 \mathrm{~m})$ separated $(1 \mathrm{~m})$ by electrical fences from the adjacent pen to avoid physical contact with animals from the other dyads. Heifers were fed a TMR composed of ground corn grain, soybean meal, corn or pasture silage, and a commercial premix [calcium carbonate, magnesium oxide, sodium bicarbonate, Rumensin (Elanco Animal Health, Indianapolis, IN), salt, yeasts], with a 60:40 forage to concentrate ratio. On d 46 of the study, due to availability, corn silage was substituted by pasture silage (Table 1 ). The TMR was formulated to a target gain of $800 \mathrm{~g} / \mathrm{d}$ of $\mathrm{BW}$ according to NRC (2001), and with the recommended MP to ME ratio so 
as to not alter mammary gland development (Albino et al., 2015). Ration and silage were mixed every day at $0700 \mathrm{~h}$ and offered once daily to each dyad between 0730 and $0830 \mathrm{~h}$.

Heifers had an initial adaptation period of $20 \mathrm{~d}$ (total study period $=140 \mathrm{~d}$ ), in which they were allocated in dyads and acclimated to the experimental conditions. In addition, during the adaptation period, the potential DMI of each dyad was determined by weighing the TMR offered and refused each day. The potential DMI was considered when $<3 \%$ orts was left for at least 3 consecutive days. Afterward, and to maximize competition between heifers, the amount offered to each dyad was restricted by $5 \%$. Each dyad had access to the same feeder $(60 \mathrm{~cm})$ throughout the experiment. The amount of feed offered was adjusted after each time heifers were weighed (considering the mean BW of each dyad). Water was available ad libitum in 2 water bowls/pen. During half of the study $(60 \mathrm{~d})$, mean temperatures were $>23^{\circ} \mathrm{C}$ (range: $22-31^{\circ} \mathrm{C}$ ) and the temperature-humidity index was $>72$ (range: 72 to 86; INIA La Estanzuela, Colonia, Uruguay), which corresponded to mild to moderate levels of heat stress (Dash et al., 2016).

\section{Social Dominance Determination}

The dominant and subordinate heifer in each dyad were determined by observing agonistic interactions in each dyad for 15 min at the moment the TMR was delivered on d 0 (after the adaptation period), 2 more times in the first month of the experiment, and every month afterward. Agonistic interactions included the following: fighting (animals head to head and pushing each other), butting (violent contact of the head on the body of the other animal), threatening (same movement as butting but without contact), and flight (animal turning the head or moving away when another approaches without threat or butt). The animal that performed more winning interactions was determined as dominant, and the other animal was the subordinate.

\section{Body Growth}

Body weight, BCS, heart girth (HG), withers height (WH), and rump fat thickness (RFT) were measured every $20 \mathrm{~d}$ in all the heifers. Heifers were weighed in the morning, before the TMR was supplied, using a portable electronic scale. The ADG $(\mathrm{kg} / \mathrm{d})$ was calculated as the ratio of weight difference between each BW and days. Body condition score was determined by visual observation using a scale adapted for heifers (range 1 to 5; Heinrichs and Jones, 2016) by the same observer. The HG was determined with an inelastic measuring tape placed just behind the front legs and behind the shoulders of the heifer. When measuring $\mathrm{WH}$, the animal was held on a level surface and a ruler was placed next to the forelegs. A level was used to ensure that the adjustable part (on the heifer's withers) was parallel to the floor when the highest point of the withers was measured (the high point of the back located at the base of the neck and between the shoulder blades). The RFT (the subcutaneous fat layer located between the skin and the fascia trunci profunda above the gluteus medium and the biceps femoris muscles) was measured by ultrasound (Ayres et al., 2009). After animal immobilization, a 5.0-MHz linear transducer (Aloka 500, Aloka Medical Ltd., Tokyo, Japan) was located linearly between hooks and pins at the sacral examination site and moved until the correct image was viewed, allowing the operator to distinguish the superior limit of biceps femoris muscle. The distance between the inferior limit of skin and the fascia trunci profunda was measured, excluding the skin thickness.

\section{Reproductive Development}

At the beginning of the experiment, anestrus was determined in all heifers by 2 consecutive ovarian scans $7 \mathrm{~d}$ apart. Thereafter, starting on d 0, ovarian scans were performed weekly in all heifers using an Aloka 500 (Aloka Medical Ltd.) ultrasound scanner with a $5.0-\mathrm{MHz}$ linear transducer. In each scan, the diameter of the greatest follicle (maximum follicle diameter, MFD), number of follicles $>6 \mathrm{~mm}$, and the presence of corpus luteum were recorded. The onset of puberty was considered the first date of 2 successive scans (separated by $7 \mathrm{~d}$ ) in which a corpus luteum was observed in the same ovary. Ovarian scanning ended when each heifer achieved puberty.

\section{Metabolic Hormones and Metabolites}

Blood samples were collected every $20 \mathrm{~d}$ from coccygeal vein before feeding, in 2 tubes, one dry, and another with sodium citrate (to determine glycemia). Samples were centrifuged $\left(3,000 \times g\right.$ for $15 \mathrm{~min}$ at $\left.4^{\circ} \mathrm{C}\right)$ within $2 \mathrm{~h}$ after collection, and serum was stored at $-20^{\circ} \mathrm{C}$ until measurements were performed. Insulin concentrations were quantified by an immunoradiometric assay (DIASource ImmunoAssays S.A., Louvain-la-Neuve, Belgium). The sensitivity of the assay was $1 \mu \mathrm{IU} / \mathrm{mL}$; intraassay coefficient of variation (CV) for low $(22.8$ $\mu \mathrm{IU} / \mathrm{mL})$ and high $(89.5 \mu \mathrm{IU} / \mathrm{mL})$ controls was 10 and $7.5 \%$, respectively. Concentrations of IGF-I were quantified by RIA (Cisbio Bioassays, Codolet, France). The sensitivity of the assay was $1 \mathrm{ng} / \mathrm{mL}$; intraassay 
Table 2. Body growth parameters in dominant $(\mathrm{n}=8)$ and subordinate $(\mathrm{n}=8)$ prepubertal dairy heifers maintained under competitive situations over $120 \mathrm{~d}$; heifers were allocated in dyads and received a TMR daily

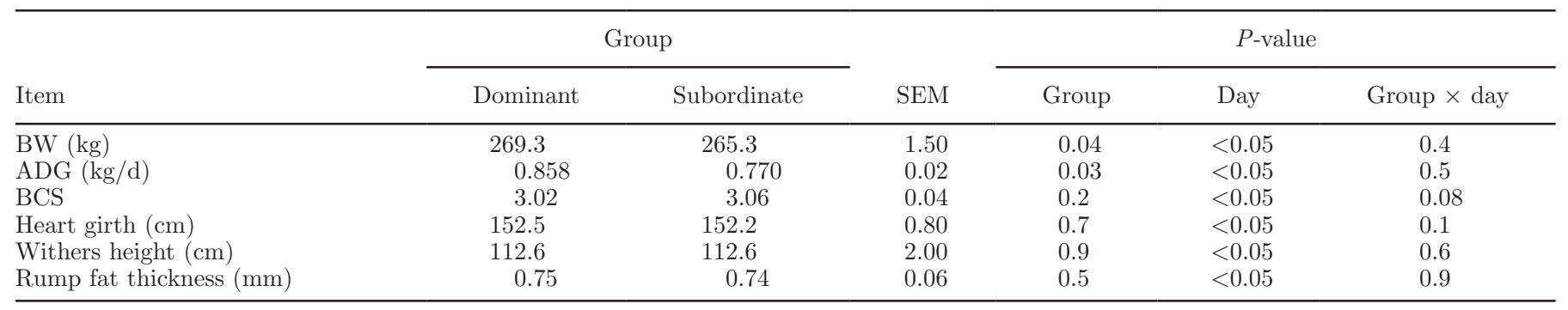

CV was 3.3 and $19 \%$ for low $(39.7 \mathrm{ng} / \mathrm{mL})$ and high $(397.4 \mathrm{ng} / \mathrm{mL})$ controls, respectively. Both the insulin and IGF-I assays were previously used in bovines (Astessiano et al., 2015). Glucose, cholesterol, and urea concentrations were determined spectrophotometrically (Vitalab, Selectra 2 autoanalyzer; Vital Scientific, Dieren, the Netherlands) using commercial enzymatic kits (Wiener Lab Group, Rosario, Argentina). All samples were determined in the same assay for each metabolite, and quality assurance was provided by including internal quality controls in each assay.

\section{TMR Chemical Analysis}

Samples of TMR were collected at d 17, 78, and 112 of the experiment during 5 consecutive days. Individual samples were composited and analyzed for DM, ash, total N, and ether extract (AOAC, 1990; methods 934.01, 942.05, 955.04, and 920.39, respectively), and for NDF and ADF (sequentially using a thermostable $\alpha$-amylase and sodium sulfite; Van Soest et al., 1991).

\section{Statistical Analysis}

Data were analyzed in a randomized block design using SAS software (SAS Institute Inc., Cary, NC). Body growth, follicular development, and metabolic and endocrine profile data were analyzed as repeated measures using PROC MIXED, with day as the repeated effect, spatial power law (for unevenly spaced data) as the covariance structure, and the Kenward-Roger procedure to adjust the degree of freedom. Heifer was the experimental unit. The model included the fixed effects of the group (dominant and subordinate), the day of the experiment, and their interaction as main effects, and dyad and animal as random effects. The heifers' birth date was included in the model as co-variable if $P$ $<0.2$. Age and BW at puberty and the day of the experiment on which heifers began cycling were compared by paired $t$-test. Significant differences were considered when $P \leq 0.05$ and tendencies as $0.05<P \leq 0.1$. The results are presented as mean \pm SEM.

\section{RESULTS}

All recordings of body growth (BW, BCS, HG, WH, and RFT) increased during the experimental period $(P<0.05)$ in both groups of heifers. Heifer BW and ADG along the study were greater in dominant than in subordinate heifers $(P<0.05)$, with no interaction between group and day (Table 2). Social dominance did not influence heifer BCS, HG, WH, or RFT (Table 2).

The total number of follicles did not differ between groups (Table 3$)$ but there was a tendency $(P=0.10)$ for an interaction between group and day: on d $30(P=$ $0.10), 37(P=0.01)$, and $53(P=0.07)$ dominant heifers had more follicles than subordinate heifers, whereas on d 70, subordinate heifers tended to have more follicles than dominant heifers $(P=0.06$; Figure 1$)$. The MFD was greater in dominant than in subordinate heifers (Table 3 ) and tended to differ between days $(P$ $=0.07$ ), with no interaction between group and day. The number of follicles $>6 \mathrm{~mm}$ differed between days $(P<0.05)$, with no group effect or interaction between group and day. Dominant heifers achieved puberty earlier than subordinate heifers $(P=0.01)$ but without differences in BW (Table 3). Dominant heifers tended to begin their cyclic activity (puberty) earlier in the experiment than subordinate heifers $[70.3 \pm 7.4$ (range $=45-97)$ and $84.0 \pm 3.8($ range $=70-97)$, respectively $(P=0.06)]$. Those days of the experiment correspond to the age of heifers at puberty in each group (Table 3 ).

Insulin and IGF-I concentrations did not differ between groups (Table 4) but differed throughout the experiment with no interaction between group and day. Dominant heifers had greater glucose concentrations than subordinate heifers $(P=0.01)$, whereas subordinate heifers had greater cholesterol concentrations than dominant heifers $(P=0.02$; Table 4 and Figure 2). In contrast, urea concentrations did not differ between 


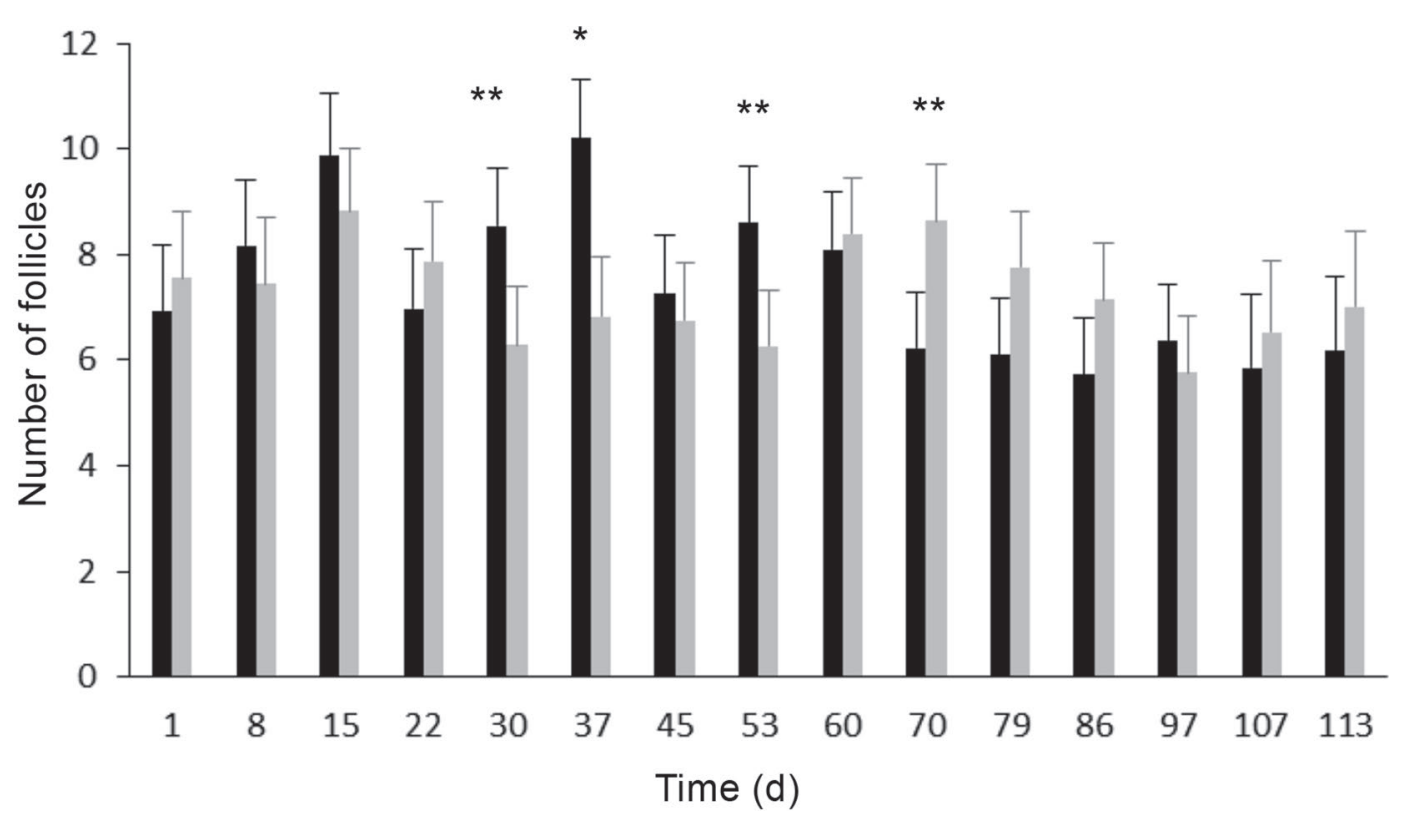

Figure 1. Total number of ovarian follicles in dominant $(\mathrm{n}=8$; black bars $)$ and subordinate $(\mathrm{n}=8$; gray bars $)$ prepubertal dairy heifers maintained in competitive situations over $120 \mathrm{~d}$. Heifers were allocated in dyads and received a TMR daily. Asterisks at each day indicate difference among the groups: ${ }^{*} P<0.05 ;{ }^{*} 0.05<P \leq 0.1$. Error bars represent SEM.

groups (Table 4). There was no interaction between group and day for any metabolite.

\section{DISCUSSION}

According to our knowledge, this is the first study demonstrating that social dominance in heifers maintained under continuous competitive situations directly affects their reproductive development, body growth, and some metabolic parameters. An earlier puberty is associated with increased size of the dominant follicle in beef heifers (Bergfeld et al., 1994), and dominant heifers had greater MFD throughout the study and more follicles than subordinate heifers from d 30 to 53, which corresponded to the period immediately before the onset of cyclic activity (d 45-50). The age at puberty was consistent with that in other studies in which dairy heifers achieved similar growth rates (Chelikani et al., 2003; Davis Rincker et al., 2011), including de Trinidad (2014), who worked in similar local conditions. Body weight at puberty did not differ between dominant and subordinate heifers, which agrees with studies reporting that puberty occurs at a regular BW and body composition, independent of dietary manipulation (Chelikani et al., 2003). Thus, management conditions and heifers' social status during the rearing period could be associated with reproductive development and performance at first breeding. Considering that the fertility of heifers increases if they have more cycles before breeding (Byerley et al., 1987), age at puberty directly affects pregnancy rates at first service, especially when heifers are bred to calve at 24 mo of age (Perry, 2012). Therefore, better fertility of dominant heifers than subordinate heifers may be expected at first service,

Table 3. Reproductive development in dominant $(\mathrm{n}=8)$ and subordinate $(\mathrm{n}=8)$ prepubertal dairy heifers maintained under competitive situations over $120 \mathrm{~d}$; heifers were allocated in dyads and received a TMR daily

\begin{tabular}{|c|c|c|c|c|c|c|}
\hline \multirow[b]{2}{*}{ Item } & \multicolumn{2}{|c|}{ Group } & \multirow[b]{2}{*}{ SEM } & \multicolumn{3}{|c|}{$P$-value } \\
\hline & Dominant & Subordinate & & Group & Day & Group $\times$ Day \\
\hline $\operatorname{MFD}^{1}(\mathrm{~mm})$ & 10.0 & 9.0 & 0.30 & 0.05 & 0.07 & 0.5 \\
\hline No. of follicles $>6 \mathrm{~mm}$ & 1.7 & 1.9 & 0.10 & 0.2 & $<0.05$ & 0.2 \\
\hline Age at puberty $(\mathrm{d} \pm \mathrm{SEM})$ & $313.9 \pm 4.9$ & $329.6 \pm 5.7$ & - & 0.01 & - & - \\
\hline $\mathrm{BW}$ at puberty $(\mathrm{kg} \pm \mathrm{SEM})$ & $279.4 \pm 2.6$ & $277.1 \pm 5.8$ & - & 0.7 & - & - \\
\hline
\end{tabular}

\footnotetext{
${ }^{1}$ Maximum follicle diameter.
} 
Table 4. Hormones and metabolites concentrations ${ }^{1}$ in dominant $(\mathrm{n}=8)$ and subordinate $(\mathrm{n}=8)$ prepubertal dairy heifers maintained under competitive situations over $120 \mathrm{~d}$; heifers were allocated in dyads and received a TMR daily

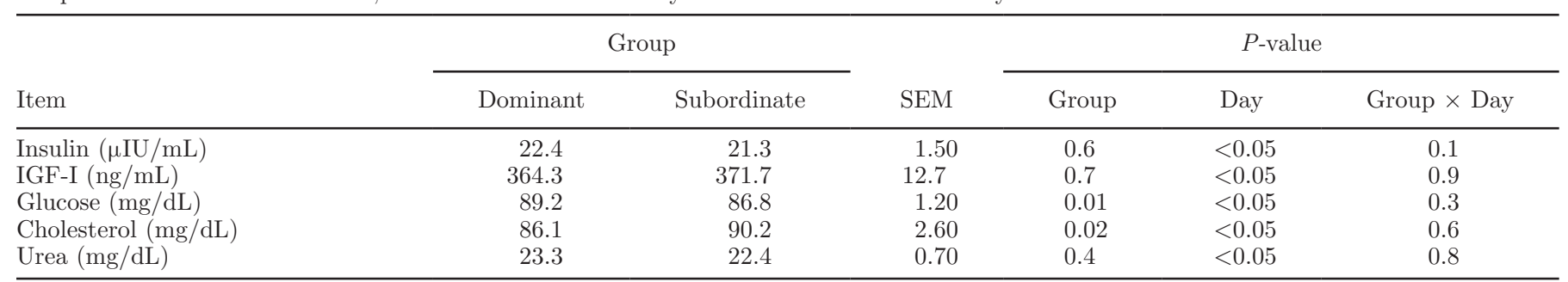

${ }^{1}$ Blood samples were taken every $20 \mathrm{~d}$.

especially if they are going to be bred at 15 mo of age. Further long-term studies are needed to confirm this hypothesis.

Follicular development (Mackey et al., 1999; Bossis et al., 2000) and onset of puberty in heifers (Schillo et al., 1992; Funston et al., 2012; Perry, 2012) are directly related to nutritional status and thus, to changes in metabolic profile. Age at puberty is highly related to prepubertal ADG, both in beef and dairy heifers: greater

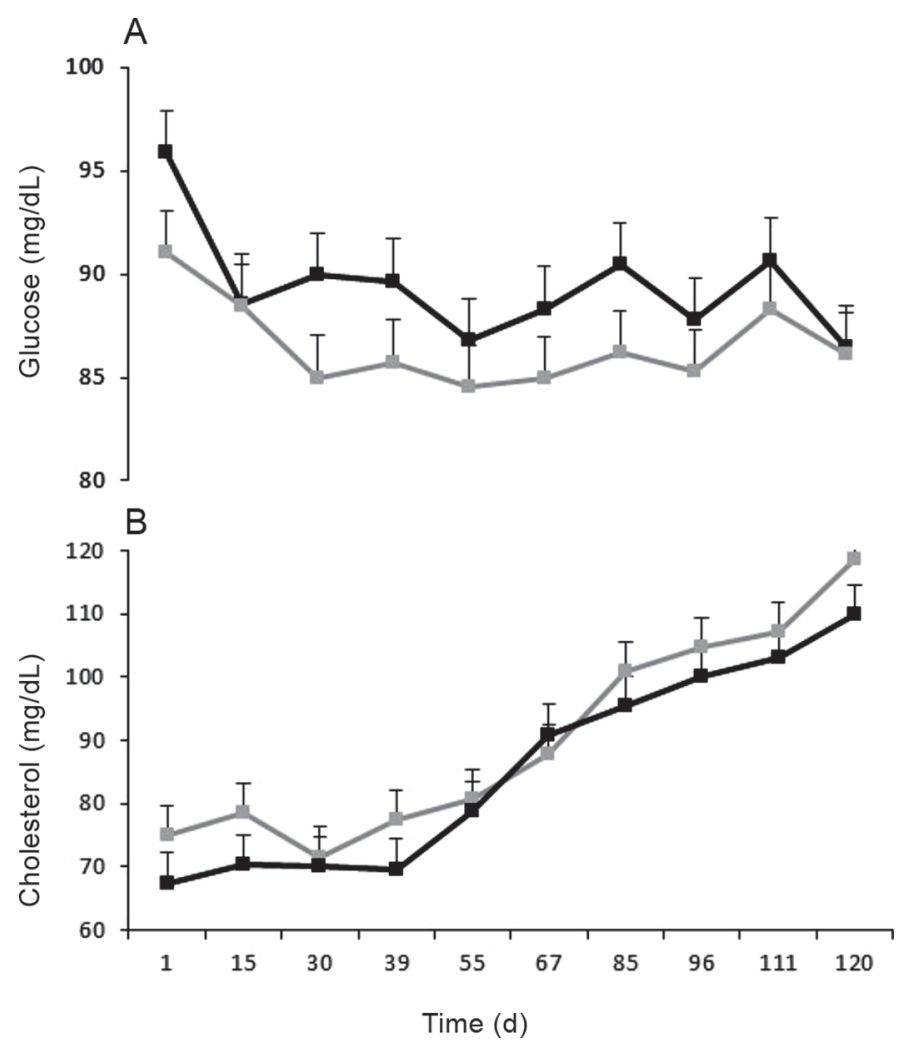

Figure 2. Concentrations of (A) glucose and (B) cholesterol in dominant $(\mathrm{n}=8$; black lines $)$ and subordinate $(\mathrm{n}=8$; gray lines $)$ prepubertal dairy heifers maintained in competitive situations over 120 d. Heifers were allocated in dyads and received a TMR daily. In both metabolites, we detected a group effect $(P<0.05)$. Error bars represent SEM. nutritional status and ADG hasten the onset of cyclic activity (Amstalden et al., 2000; Chelikani et al., 2003). Dominant heifers had greater ADG than subordinate heifers, which is in agreement with larger dominant follicles at a younger age in dominant compared with subordinate heifers (Bergfeld et al., 1994; Chelikani et al., 2003). Although the exact role of glucose in the reproductive function of female ruminants is still not fully elucidated (Haldar and Prakash, 2007; Sabia et al., 2014), greater ADG and follicular growth rates are associated with increased concentrations of glucose in prepubertal dairy heifers (Abeni et al., 2000), possibly indicating a "more positive" energy status in dominant heifers that results in greater follicular development compared with subordinate heifers. Moreover, greater glucose concentrations in dominant compared with subordinate heifers can be associated with a lower age at first breeding (Brickell et al., 2009). Previous studies reported that when competition for food increases, changes in feeding behavior, but not total DMI, affect heifers' body growth (Longenbach et al., 1999; González et al., 2008; DeVries, 2010). In this sense, we might speculate that the greater opportunity for sorting by dominant heifers could determine that they were more efficient than subordinate heifers in selecting small particles such ground corn grain in the TMR (DeVries et al., 2005; Greter et al., 2008; Ceacero et al., 2012). Thus, dominant heifers probably consumed a more energetic diet (containing more corn grain), leading to greater ruminal propionate production, and thus increased serum glucose concentrations compared with subordinate heifers (Wiltrout and Satter, 1972). Therefore, changes in feeding behavior, food utilization, or both between heifers of different social status determined increased ADG and glucose concentrations in dominant compared with subordinate heifers, which ultimately affected their reproductive performance. Considering these results, management conditions that determined high levels of competition could lead not only to differences in ADG and BW between animals of different social status, but also to differences in 
metabolic status and reproductive performance. In this sense, the animals' housing (increase feeding space, do not overstock) becomes very important to decrease competition levels, and thus welfare concerns, in heiferrearing systems.

The greater cholesterol concentrations observed in subordinate than in dominant heifers was not expected because, like glucose, cholesterol is positively related to energy status (McShane et al., 1989) and to ovarian function (Talavera et al., 1985). Cholesterol uptake is the main source for the synthesis of steroid hormones (Yart et al., 2014), and plasma progesterone concentrations are negatively correlated with plasma cholesterol concentrations (Talavera et al., 1985). Thus, as progesterone increases when cyclic activity begins, lower cholesterol levels in dominant heifers could be associated with their earlier puberty compared with subordinate heifers (Rodríguez-Sánchez et al., 2015). A different explanation could be related to the environmental conditions: during an important period of the study, heifers were under heat stress (temperature-humidity index >72; Dash et al., 2016), and it has been reported that cholesterol concentrations are greater in animals that suffer more heat stress (Scharf et al., 2010). As social rank can influence the response to specific stressors (Sutherland et al., 2007), subordinate heifers could be more affected by heat stress than dominant heifers, resulting in increased cholesterol levels. In addition, heat-stressed animals have lower glucose concentrations (Shaffer et al., 1981; Nonaka et al., 2008), as seen in the subordinate heifers in our study. Stress involves the reaction of an animal to harsh environments and it has unfavorable consequences in animal performance (Das et al., 2016). In this sense, heat stress affects reproductive performance in cattle (Dash et al., 2016); thus, the greater heat stress in subordinate heifers could have affected follicular development and increased age at puberty compared with dominant heifers.

\section{CONCLUSIONS}

Under continuous competitive situations, dominant heifers were more precocious than subordinate ones, achieving an earlier puberty. Dominant heifers had greater body growth and glucose concentrations than subordinate heifers, which may be responsible, at least in part, for the differences in reproductive development between heifers of different social status.

\section{ACKNOWLEDGMENTS}

We are especially grateful to Martin Aguerre, Ma. Noel Méndez, Augusto Lacava, Ignacio Donadio, Annie dos Santos, Leticia Eustathiou, Ana Maverino, Guillermo Matto, Verónica Sánchez, Francisco Triay, and Federico de León (Facultad de Veterinaria, Uruguay) for their help with animal management. We also thank Maximiliano Pastorini, Gustavo Cazard, Damián Sosa, Elena de Torres (director of the Campo Experimental), Ana Laura Astessiano, and Alberto Casal (Facultad de Agronomia, Uruguay) for their help on hormone analysis, and Laura Pereira de Souza (Columbia University, New York, NY) for language revision. This study was financially supported by Comisión Sectorial de Investigación Científica (CSIC VUSP_45), Universidad de la República, Montevideo, Uruguay.

\section{REFERENCES}

Abeni, F., L. Calamari, L. Stefanini, and G. Pirlo. 2000. Effects of daily gain in pre- and postpubertal replacement dairy heifers on body condition score, body size, metabolic profile, and future milk production. J. Dairy Sci. 83:1468-1478.

Abeni, F., L. Calamari, L. Stefanini, and G. Pirlo. 2012. Effect of average daily gain on body size, metabolism, and milk production of Italian Holstein heifers raised on two different planes of nutrition and calving at two different ages. Livest. Sci. 149:7-17. https:// doi.org/10.1016/j.livsci.2012.06.003.

Albino, R. L., M. I. Marcondes, R. M. Akers, E. Detmann, B. C. Carvalho, and T. E. Silva. 2015. Mammary gland development of dairy heifers fed diets containing increasing levels of metabolisable protein:metabolisable energy. J. Dairy Res. 82:113-120.

Amstalden, M., M. R. Garcia, S. W. Williams, R. L. Stanko, S. E. Nizielski, C. D. Morrison, D. H. Keisler, and G. L. Williams. 2000. Leptin gene expression, circulating leptin, and luteinizing hormone pulsatility are acutely responsive to short-term fasting in prepubertal heifers: Relationships to circulating insulin and insulin-like growth factor I. Biol. Reprod. 63:127-133.

AOAC. 1990. Official Methods of Analysis. 15th ed. AOAC, Arlington, VA.

Astessiano, A. L., A. Meikle, M. Fajardo, J. Gil, D. A. Mattiauda, P. Chilibroste, and M. Carriquiry. 2015. Metabolic and endocrine profiles and hepatic gene expression of Holstein cows fed total mixed ration or pasture with different grazing strategies during early lactation. Acta Vet. Scand. 57:70-82. https://doi.org/10.1186/ s13028-015-0163-6.

Ayres, H., R. Machado Ferreira, J. R. de Souza Torres-Júnior, C. G. Borges Demétrio, C. Gonçalves de Lima, and P. S. Baruselli. 2009. Validation of body condition score as a predictor of subcutaneous fat in Nelore (Bos indicus) cows. Livest. Sci. 123:175-179. https:// doi.org/10.1016/j.livsci.2008.11.004.

Bergfeld, E. G. M., F. N. Kojima, A. S. Cupp, M. E. Wehrman, K. E. Peters, M. Garcia-Winder, and J. E. Kinder. 1994. Ovarian follicular development in prepubertal heifers is influenced by level of dietary energy intake. Biol. Reprod. 51:1051-1057.

Bossis, I., R. P. Wettemann, S. D. Welty, J. Vizcarra, and L. J. Spicer. 2000. Nutritionally induced anovulation in beef heifers: Ovarian and endocrine function during realimentation and resumption of ovulation. Biol. Reprod. 62:1436-1444.

Brickell, J. S., M. M. McGowan, and D. C. Wathes. 2009. Effect of management factors and blood metabolites during the rearing period on growth in dairy heifers on UK farms. Domest. Anim. Endocrinol. 36:67-81. https://doi.org/10.1016/j.domaniend.2008.10.005.

Byerley, D. J., R. B. Staigmillet, J. G. Berardinelli, and R. E. Short. 1987. Pregnancy rates of beef heifers bred either on puberal or third estrus. J. Anim. Sci. 65:645-650.

Ceacero, F., A. J. García, T. Landete-Castillejos, J. Bartosova, L. Bartos, and L. Gallego. 2012. Benefits for dominant red deer hinds 
under a competitive feeding system: food access behavior, diet and nutrient selection. PLoS One 7:e32780 https://doi.org/10.1371/ journal.pone.0032780.

Chelikani, P. K., J. D. Ambrose, and J. J. Kennelly. 2003. Effect of dietary energy and protein density on body composition, attainment of puberty, and ovarian follicular dynamics in dairy heifers. Theriogenology 60:707-725. https://doi.org/10.1016/S0093691X(03)00088-8.

Conaprole. 2008. Recria Intensiva de los Reemplazos. Ficha Técnica No. 8 1ra Ed. J. L Repetto, C. Cajarville, A. Mendoza, and G. Oleggini, ed. http://www.eleche.com.uy/files/ficha-8-recriaintensiva-990?es.

Das, R., L. Sailo, N. Verma, P. Bharti, J. Saikia, Imtiwati, and R. Kumar. 2016. Impact of heat stress on health and performance of dairy animals: A review. Vet. World 9:260-268. 1014202/ vetworld.2016.260-268.

Dash, S., A. K. Chakravarty, A. Singh, A. Upadhyay, M. Singh, and S. Yousuf. 2016. Effect of heat stress on reproductive performances of dairy cattle and buffaloes: A review. Vet. World 9:235-244. https://doi.org/10.14202/vetworld.2016.235-244.

Davis Rincker, L. E., M. J. VandeHaar, C. A. Wolf, J. S. Liesman, L. T. Chapin, and M. S. Weber Nielsen. 2011. Effect of intensified feeding of heifer calves on growth, pubertal age, calving age, milk yield, and economics. J. Dairy Sci. 94:3554-3567. https://doi. org/10.3168/jds.2010-3923.

de Trinidad, S. 2014. Alimentación diferencial durante la etapa lactante en terneras Holstein: Efectos inmediatos y residuales sobre el crecimiento, desarrollo corporal y pubertad. MS Thesis, Programa de Posgrados de la Facultad de Veterinaria, Montevideo, Uruguay.

DeVries, T. J., M. A. G. von Keyserlingk, and K. A. Beauchemin. 2005. Frequency of feed delivery affects the behavior of lactating dairy cows. J. Dairy Sci. 88:3553-3562. https://doi.org/10.3168/ jds.S0022-0302(05)73040-X.

DeVries, T. J. 2010. Review: Behaviour and its role in the nutritional management of the growing dairy heifer. Can. J. Anim. Sci. 90:295-302.

Dobson, H., and R. F. Smith. 2000. What is stress, and how does it affect reproduction? Anim. Reprod. Sci. 60-61:743-752.

Drews, C. 1993. The concept and definition of dominance in animal behaviour. Behaviour 125:283-313. https://doi org/10.1163/156853993X0090

Funston, R. N., J. L. Martin, D. M. Larson, and A. J. Roberts. 2012. Physiology and Endocrinology symposium: Nutritional aspects of developing replacement heifers. J. Anim. Sci. 90:1166-1171. https://doi.org/10.2527/jas.2011-4569.

González, L. A., A. Ferret, X. Manteca, J. L. Ruiz-de-la-Torre, S. Calsamiglia, M. Devant, and A. Bach. 2008. Performance, behavior, and welfare of Friesian heifers housed in pens with two, four, and eight individuals per concentrate feeding place. J. Anim. Sci. 86:1446-1458. https://doi.org/10.2527/jas.2007-0675.

Greter, A. M., T. J. DeVries, and M. A. von Keyserlingk. 2008. Nutrient intake and feeding behavior of growing dairy heifers: Effects of dietary dilution. J. Dairy Sci. 91:2786-2795. https://doi. org/10.3168/jds.2008-1052.

Greter, A. M., K. E. Leslie, G. J. Mason, B. W. McBride, and T. J. DeVries. 2010. Effect of feed delivery method on the behavior and growth of dairy heifers. J. Dairy Sci. 93:1668-1676. https://doi. org/10.3168/jds.2009-2844.

Haldar, A., and B. S. Prakash. 2007. Effect of exogenous growth-hormone-releasing factor on blood metabolites and minerals in late maturing buffalo heifers (Bubalus bubalis). J. Anim. Physiol. Anim. Nutr. (Berl.) 91:326-332.

Heinrichs, A. J., and C. Jones. 2016. Monitoring dairy heifer growth Penn State Collage of Agricultural Sciences. Accessed May 20, 2016. http://extension.psu.edu/animals/dairy/nutrition/heifers.

Heinrichs, A. J., and L. A. Swartz. 1990. Management of dairy heifers. Pennsylvania State Univ. Ext. Circ. 385. Pennsylvania State University, University Park.

Landaeta-Hernández, A. J., P. Meléndez, J. Bartolomé, D. O. Rae, and F. Archbald. 2013. Effect of biostimulation and social orga- nization on the interval from calving to resumption of ovarian cyclicity in postpartum Angus cows. Theriogenology 79:1041-1044. https://doi.org/10.1016/j.theriogenology.2013.01.020.

Longenbach, J. I., A. J. Heinrichs, and R. E. Graves. 1999. Feed bunk length requirements for Holstein dairy heifers. J. Dairy Sci. 82:99 109.

Mackey, D. R., J. M. Sreenan, J. F. Roche, and M. G. Diskin. 1999 Effect of acute nutritional restriction on incidence of anovulation and periovulatory estradiol and gonadotropin concentrations in beef heifers. Biol. Reprod. 61:1601-1607.

Manteca, X. 2009. Etología Veterinaria. 1st ed. Multimédica Ediciones Veterinarias, Barcelona, Spain.

McShane, T. M., K. K. Schillo, J. A. Boling, N. W. Bradley, and J. B. Hall. 1989. Effects of recombinant DNA-derived somatotropin and dietary energy intake on development of beef heifers: I. Growth and puberty. J. Anim. Sci. 67:2230-2236.

NRC. 2001. Nutrient Requirements of Dairy Cattle. 7th rev. ed. Natl Acad. Press, Washington DC.

Nonaka, I., N. Takusari, K. Tajima, T. Suzuki, K. Higuchi, and M. Kurihara. 2008. Effects of high environmental temperatures on physiological and nutritional status of prepubertal Holstein heifers. Livest. Sci. 113:14-23. https://doi.org/10.1016/j.livsci.2007.02.010.

Perry, G. A. 2012. Physiology and Endocrinology symposium: Harnessing basic knowledge of factors controlling puberty to improve synchronization of estrus and fertility in heifers. J. Anim. Sci 90:1172-1182. https://doi.org/10.2527/jas.2011-4572.

Phillips, C. J. C., and M. I. Rind. 2002. The effects of social dominance on the production and behavior of grazing dairy cows offered forage supplements. J. Dairy Sci. 85:51-59.

Pirlo, G., F. Miglior, and M. Speroni. 2000. Effect of age at first calving on production traits and on difference between milk yield returns and rearing costs in Italian Holsteins. J. Dairy Sci. 83:603-608.

Rodríguez-Sánchez, J. A., A. Sanz, C. Tamanini, and I. Casasús 2015. Metabolic, endocrine, and reproductive responses of beef heifers submitted to different growth strategies during the lactation and rearing periods. J. Anim. Sci. 93:3871-3885. https://doi. org/10.2527/jas.2015-8994.

Sabia, E., F. Napolitano, G. De Rosa, G. M. Terzano, V. L. Barile, A. Braghieri, and C. Pacelli. 2014. Efficiency to reach age of puberty and behaviour of buffalo heifers (Bubalus bubalis) kept on pasture or in confinement. Animal 8:1907-1916. https://doi.org/10.1017/ S1751731114001876.

Scharf, B., J. A. Carroll, D. G. Riley, C. C. Chase, S. W. Coleman, D. H. Keisler, R. L. Weaber, and D. E. Spiers. 2010. Evaluation of physiological and blood serum differences in heat-tolerant (Romosinuano) and heat-susceptible (Angus) Bos taurus cattle during controlled heat challenge. J. Anim. Sci. 88:2321-2336. https://doi. org $/ 10.2527 /$ jas.2009-2551.

Schillo, K. K., J. B. Halls, and S. M. Hileman. 1992. Effects of nutrition and season on the onset of puberty in the beef heifer. J. Anim. Sci. 70:3994-4005.

Shaffer, L., J. D. Roussel, and K. L. Koonce. 1981. Effects of age, temperature-season, and breed on blood characteristics of dairy cattle. J. Dairy Sci. 64:62-70.

Stewart, T. S., C. R. Long, and T. C. Cartwright. 1980. Characterization of cattle of a five-breed diallel. II. Puberty in bulls and heifers. J. Anim. Sci. 50:808-820.

Sutherland, M. A., S. R. Niekamp, R. W. Johnson, W. G. Van Alstine, and J. L. Salak-Johnson. 2007. Heat and social rank impact behavior and physiology of PRRS-virus-infected pigs. Physiol. Behav 90:73-81. https://doi.org/10.1016/j.physbeh.2006.08.029.

Talavera, F., C. S. Park, and G. L. Williams. 1985. Relationships among dietary lipid intake, serum cholesterol and ovarian function in Holstein heifers. J. Anim. Sci. 60:1045-1051.

Tozer, P. R., and A. J. Heinrichs. 2001. What affects the costs of raising replacement dairy heifers: a multiple-component analysis. J. Dairy Sci. 84:1836-1844.

Ungerfeld, R., and S. P. González-Pensado. 2008. Social rank affects reproductive development in male lambs. Anim. Reprod. Sci 109:161-171. https://doi.org/10.1016/j.anireprosci.2007.12.006. 
Val-Laillet, D., A. M. de Passille, J. Rushen, and M. von Keyserlingk. 2008. The concept of social dominance and the social distribution of feeding-related displacements between cows. Appl. Anim. Behav. Sci. 111:158-172. https://doi.org/10.1016/j.applanim.2007.06.001.

Van Soest, P. J., J. B. Robertson, and B. A. Lewis. 1991. Symposium: Carbohydrate methodology, metabolism, and nutritional implications in dairy cattle. Methods for dietary fiber, neutral detergent fiber, and nonstarch polysaccharides in relation to animal nutrition. J. Dairy Sci. 74:3583-3597.

Wiltrout, D. W., and L. D. Satter. 1972. Contribution of propionate to glucose synthesis in the lactating and nonlactating cow. J. Dairy Sci. 55:307-317.

Yart, L., V. Lollivier, P. G. Marnet, and F. Dessauge. 2014. Role of ovarian secretions in mammary gland development and func- tion in ruminants. Animal 8:72-85. https://doi.org/10.1017/ S1751731113001638

Yelich, J. V., R. P. Wettemann, H. G. Dolezal, K. S. Lusby, D. K. Bishop, and L. J. Spicer. 1995. Effects of growth rate on carcass composition and lipid partitioning at puberty and growth hormone, insulin-like growth factor I, insulin, and metabolites before puberty in beef heifers. J. Anim. Sci. 73:2390-2405.

Yelich, J. V., R. P. Wettemann, T. T. Marston, and L. J. Spicer. 1996. Luteinizing hormone, growth hormone, insulin-like growth factor-l, insulin and metabolites before puberty in heifers fed to gain at two rates. Domest. Anim. Endocrinol. 13:325-338.

Zanton, G. I., and A. J. Heinrichs. 2005. Meta-analysis to assess effect of prepubertal average daily gain of Holstein heifers on firstlactation production. J. Dairy Sci. 88:3860-3867. 